\title{
Danish type gelsolin-related amyloidosis in a Brazilian family: case reports
}

\author{
Amiloidose familiar relacionada ao gene gelsolin em uma família brasileira: relato de casos
}

\author{
Helena Parente Solari ${ }^{1}$, Marcelo Palis Ventura ${ }^{1}$, Emilia Antecka², Rubens Belfort Junior ${ }^{3}$, Miguel Noel Burnier JR. ${ }^{4}$
}

\begin{abstract}
Familial amyloidosis of the Finnish type (FAF) is an autosomal dominant form of systemic amyloidosis showing marked geographic clustering in Finland. The disease is caused by a point mutation, 654G-A, in the gelsolin gene. The Danish-subtype of FAF has been previously described in three families, the patients present clinical findings similar to FAF, and the mutation 654G-T in the gelsolin gene. Three members from two generations of the same family, with familial amyloidosis, were screened for mutations in the GSN gene. Genomic DNA was extracted from peripheral blood lymphocytes and the polymerase chain reaction (PCR) was carried out under standard conditions, using appropriate primers. Sequence analysis showed the presence of a $\mathrm{G}$ to $\mathrm{T}$ transition at nucleotide 654 of the gelsolin gene. This is the first report of gelsolin-related familial amyloidosis in a Brazilian family, and the result is particularly significant as this pedigree presents an unusual mutation, described previously in three families, with no known Finnish ancestors (Danish type).
\end{abstract}

Keywords: Amyloidosis; Gelsolin; Corneal dystrophies, hereditary; Cornea/pathology; Humans; Female; Male; Adult; Case reports

\begin{abstract}
RESUMO
Amiloidose familiar do tipo finlandes (FAF) é uma forma de amiloidose sistêmica autossômica dominante com grande concentração geográfica na Finlândia. Écausada por uma mutação, 654G-A, no gene gelsolin. O subtipo dinamarquês da FAF foi previamente descritoem trêsfamílias, comachados clínicos similares mas com a mutação654G-Tno gene gelsolin. Trêsmembros de duas gerações da mesmafamília, com diagnóstico de amiloidose familiar, foram submetidos a screening de mutações no gene gelsolin. O DNA genômico foi extraído de linfócitos do sanque periférico, sendo realizada reação em cadeia de polimerase (PCR) em condições padronizadas. A análise do sequenciamento revelou uma transição de G para T no nucleotidio 654 do gene gelsolin. Esteéo primeiro rela to de uma amiloidose familiar relacionada ao gene gelsolin em uma família brasileira, que apresenta uma forma rara de mutação, descrita previamente em três famílias, sem ancestrais finlandeses (tipo dinamarquês).
\end{abstract}

Descritores: Amiloidose; Gelsolina; Distrofia hereditária da córnea; Córnea/patologia; Humano; Feminino; Masculino; Adulto; Relato de casos

\section{INTRODUCTION}

Gelsolin-related familial amyloidosis, also known as familial amyloidosis of the Finnish type (FAF) or Meretoja syndrome, is an autosomal dominant form of systemic amyloidosis characterized by corneal lattice dystrophy, progressive cranial and peripheral neuropathy, skin changes (cutis laxa), renal and cardiac manifestations ${ }^{(1-3)}$. Corneal lattice dystrophy is usually the earliest clinical finding and is characterized by amyloid deposit within the stroma. The heterozygous patients often present with ophthalmological disturbances in the third or fourth decade of life, while the homozygotes present with earlier onset, and greater severity of clinical findings $s^{(1,4)}$. These clinical manifestations are the result of accumulation of amyloid fibrils derived from the actin-regulating protein gelsolin, which exists in two different forms, cytoplasmic or plasma, derived from the same gene by alternative splicing. The pathogenesis of the FAF disease phenotype arises from the accumulation of extracellular amyloid in tissues rather than the loss of gelsolin function.

Gelsolin-related familial amyloidosis is caused by a single nucleotide substitution in the genomic DNA sequence of the gelsolin gene (GSN), located on chromosome 9. Two gelsolin mutations have been described: the first and most common mutation, a 654G-A transition, leads to an Asp to Asn substitution at residue 187 of the protein. This mutation has been reported in all Finnish patients as well as in other countries. The second mutation is a 654G-T transversion resulting in a Asp187Tyr substitution and was found in only three families, of Danish, Czech and French origins, with similar clinical manifestations $s^{(1,2,-8)}$. We report the first case in a Brazilian family, carrying the Asp187Tyr mutation, with no known Finnish ancestors.

\section{CASE REPORTS}

The family is from Brazil and had no known ancestor from Finland. The grandfather of the proband was born in Armenia. Four members of this family from two generations were examined.

\section{CASE 1}

The proband was a single 58 year-old woman without kids who presented with gradual reduction in visual acuity of both eyes (OU). She had a characteristic facial appearance and a history of involuntary facial twitching, weakness of the chewing muscles, and a slowly progressive bilateral facial weakness, associated with loose skin on the face and head, a drooping forehead and lower lip. Examination revealed best corrected visual acuity of 20/40 (OU) and she had
Submitted for publication: October 29, 2009

Accepted for publication: November 21, 2010

Study carried out at the Department of Ophthalmology, Federal University of São Paulo - UNIFESP Genetics Department, Federal University of São Paulo - UNIFESP and The Henry C. Witelson Ocular Pathology Laboratory, McGill University.

${ }_{1}^{1}$ Professor, Universidade Federal Fluminense - UFF - Niterói (RJ), Brazil. Post-Doctorate in Ophthalmology at McGill University, Montreal - Canada.

2 Physician, The Henry C. Witelson Ocular Pathology Laboratory, McGill University, Montreal, Canada.

${ }^{3}$ Full Professor, Ophthalmology Department, Universidade Federal de São Paulo - UNIFESP - São Paulo (SP), Brazil.

${ }^{4}$ Physician, The Henry C. Witelson Ocular Pathology Laboratory, McGill University, Montreal, Canada.
Funding: No specific financial support was available for this study.

Disclosure of potential conflicts of interest: H.P.Solari, None; M.P.Ventura, None; E.Antecka, None; R.Belfort Jr., None; M.N.Burnier Jr., None.

Correspondence address: Helena Parente Solari. Av. Florestan Fernandes, 790 - Casa 49 - Niteroi (RJ) - 24358-580 - Brazil - E-mail: hpsolari@yahoo.com.br 
corneal dystrophy with lattice lines primarily in the periphery without intervening stromal haze, and bilateral corneal hypoesthesia (Figure 1). The proband had only one brother (Case 2 ).

\section{CASE 2}

The 41 year-old brother of the proband had no systemic or visual complaints. On examination both corneas showed evidence of lattice lines with bilateral corneal hypoesthesia. This patient has a 9 year old son and a 3 year old daughter with no abnormalities observed during their clinical and ophthalmological examination.

The molecular genetic study was done in cases 1,2 and in the son of case 2. The genomic DNA was extracted from peripheral blood lymphocytes using standard techniques. The polymerase chain reaction (PCR) was carried out under standard conditions in $50 \mu$ reaction volumes, $1 \mu \mathrm{g}$ of genomic DNA, 0,5 pmol each of forward and reverse primers, $10 \mathrm{mM}$ of dNTP mix, 10X PCR buffer, $50 \mathrm{mM} \mathrm{MgCl}$, and 0.2 units of Taq platinum polymerase. After an initial denaturation step at $94^{\circ} \mathrm{C}$ for 5 minutes, the samples were processed through 25 cycles of amplification consisting of $94^{\circ} \mathrm{C}$ for 1 minute, primer annealing temperature of $56^{\circ} \mathrm{C}$ for 1 minute, and extension at $72^{\circ} \mathrm{C}$ for 1 minute. The following forward (F) and reverse (R) primers were used: $5^{\prime}$ - TGGTGG TGCAGAGACTCTTCC - 3' and 5'- CITCATACCGATTGCTGTT- 3'. Direct sequencing of purified PCR products was performed using a dye terminator cycle sequencing kit (Perkin Elmer, Applied Biosystems LTD) using a fluorescent sequencer (ABI 373), according to the manufacturer's instructions.

Screening of the genomic DNA showed the G654T mutation in the gelsolin gene (GSN) in cases 1 and 2. The G substitution by a T predicts the amino acid substitution of tyrosine for the aspartate at residue 187 (Figures 2 and 3).

\section{DISCUSSION}

Two mutations in the gelsolin gene have been shown to cause FAF. The most common, a G to A transition at nucleotide 654, has been detected in all Finnish patients as well as in families of other nationalities ${ }^{(2,7,9)}$. The second mutation, a $\mathrm{G}$ to $\mathrm{T}$ transversion at nucleotide 654 , has been detected in 3 different families, and is related to the Danish type of familial amyloidosis, first described in 1979 by Boysen et al..$^{(2,7-9)}$ In this study we describe for the first time a G654T mutation in the gelsolin gene in a Brazilian family. The clinical features of this subtype are very similar to those described by Meretoja (FAF), presenting skin and neurological changes associated with lattice corneal dystrophy ${ }^{(2,9-11)}$. The main clinical features of the studied patients were caused by ophthalmic (cases 1 and 2) and dermatological manifestations (case 1), similar to what is found in FAF.

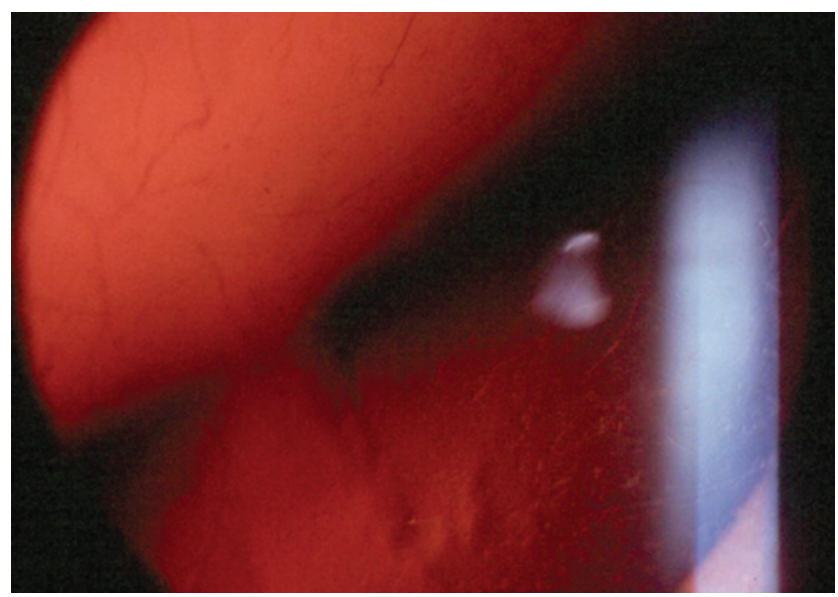

Figure 1. Biomicroscopy showing lattice corneal dystrophy in proband.
This result shows that the G654T mutation causes similar clinical findings to those related to the G654A mutation. Previous studies demonstrated that the substitution of aspartic acid at position 187 in gelsolin with either asparagine or tyrosine is associated with abnormal degradation ${ }^{(2,11)}$ Maury et al., evaluated the Danish subtype of FAF and report that the immunohistochemical and biochemical findings indicate that the G654T mutation in the gelsolin gene gives rise to an amyloid disease clinically and pathogenetically similar to that caused by the G654A mutation, as observed in case $1^{(2)}$.

The disease is an inherited, lifelong chronic condition with systemic symptoms and is probably under-reported. Because the ocular symptoms are the first to arise, as observed in our cases, the ophthalmologists should be vigilant. Treatment is symptomatic, with eye lubricants combined with monitoring of intraocular pressure, and regular ophthalmic examinations are recommended for all patients with the disease. When systemic symptoms occur, other specialists should be consulted ${ }^{(12)}$. In our study the DNA analysis identified the affected patients, which were submitted to frequent ophthalmic evaluations.

It is important to recognize that this condition can occur in populations other than in Finnish patients and should be considered in the differential diagnosis of lattice corneal dystrophy. This is not a true corneal dystrophy and can be confused with true lattice dystrophies, which in turn may delay diagnosis of the underlying systemic amyloidosis for many years, especially in populations in

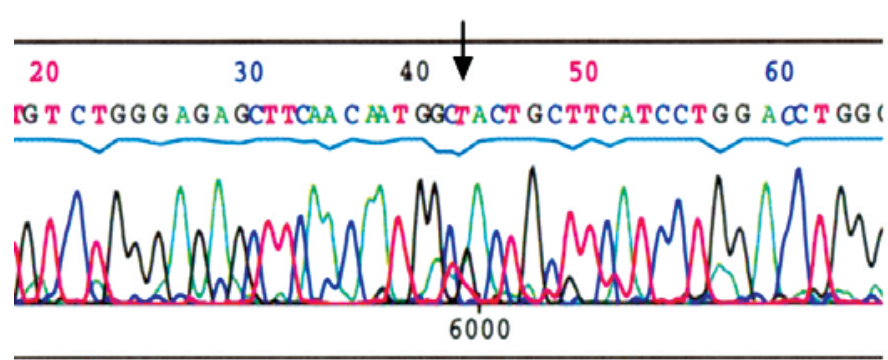

Figure 2. Pedigree of family. Affected members are shown in black and those contributing DNA marked with + symbol.

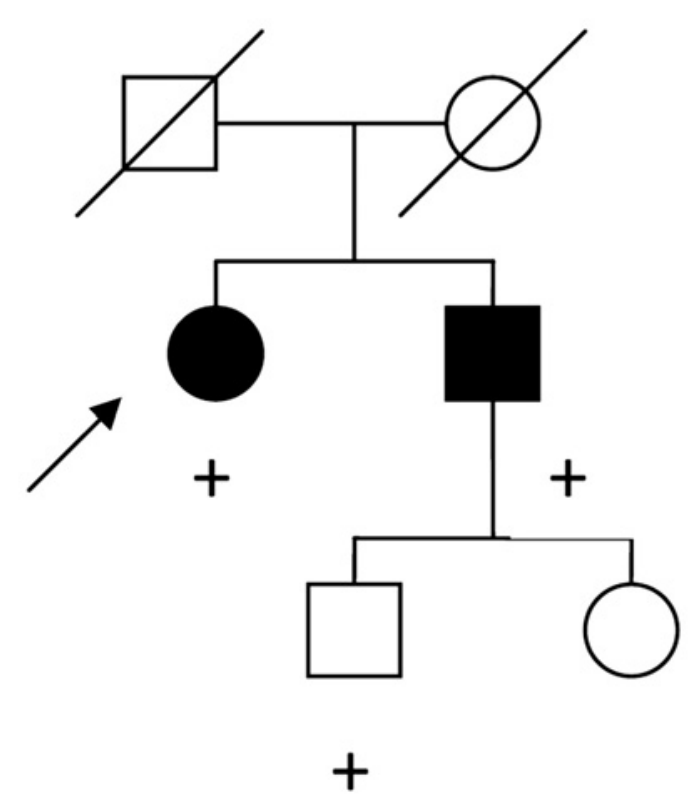

Figure 3. DNA sequencing showing the $\mathrm{G}$ substitution by a $\mathrm{T}$ at residue 187 
which this type of familial amyloidosis is rare ${ }^{(13)}$. To the best of our knowledge this is the first report of a pedigree of patients with gelsolin-related familial amyloidosis in Brazil.

\section{REFERENCES}

1. Kivelä T, Tarkkanen A, Frangione B, Ghiso J, Haltia M. Ocular amyloid deposition in familial amyloidosis, Finnish: an analysis of native and variant gelsolin in Meretoja's syndrome. Invest Ophthalmol Vis Sci. 1994;35(10):3759-69.

2. Maury CP, Liljeström M, Boysen G, Tornroth T, de la Chapelle A, Nurmiaho-Lassila EL. Danish type gelsolin related amyloidosis: 654G-T mutation is associated with a disease pathogenetically and clinically similar to that caused by the 654G-A mutation (familial amyloidosis of the Finnish type). J Clin Pathol. 2000;53(2):95-9.

3. Levy E, Haltia M, Fernandez-Madrid I, Koivunen O, Ghiso J, Prelli F, et al. Mutation in gelsolin gene in Finnish hereditary amyloidosis. J Exp Med. 1990;172(6):1865-7.

4. Conceição I, Sales-Luis ML, Carvalho M, Evangelista T, Fernandes R, Paunio T, et al. Gelsolin-related familial amyloidosis, Finnish type, in a Portuguese family: clinical and neurophysiological studies. Musc Nerve. 2003;28(6):715-21.

5. Isaacson RL, Weeds AG, Fersht AR. Equilibria and kinetics of folding of gelsolin domain 2 and mutants involved in familial amyloidosis - Finnish type. Proc Natl Acad Sci. 1999;96(20): $11247-52$
6. Rothstein A, Auran JD, Wittpenn JR, Koester CJ, Florakis GJ. Confocal microscopy in Meretoja syndrome. Cornea. 2002;21(4):364-7.

7. Chastan N, Baert-Desurmont S, Saugier-Veber P, Dérumeaux G, Cabot A, Frébourg T, et al. Cardiac conductions alterations in a French family with amyloidosis of the Finnish type with the p. Asp187 Tyr mutation in the GSN gene. Muscle Nerve. 2006;33(1):113-9.

8. Stewart HS, Parveen R, Ridgway AE, Bonshek R, Black CG. Late onset lattice corneal dystrophy with systemic familial amyloidosis, amyloidosis $\mathrm{V}$, in an English family. Br J Ophthalmol. 2000;84(4):390-4. Comment in: Br J Ophthalmol. 2000;84(8):938.

9. Boysen G, Galassi G, Kamieniecka Z, Schlaeger J, Trojaborg W. Familial amyloidosis with cranial neuropathy and corneal lattice dystrophy. J Neurol Neurosurg Psychiatry. 1979; 42(11):1020-30

10. Kwiatkowski DJ, Stossel TP, Orkin SH, Mole JE, Colten HR, Yin HL. Plasma and cytoplasmic gelsolins are encoded by a single gene and contain a duplicated actin-binding domain Nature. 1986:323(6087):455-8.

11. Haltia M, Levy E, Meretoja J, Fernandez-Madrid I, Koivunen O, Frangione B. Gelsolin gene mutation - at codon 187 - in familial amyloidosis, Finnish: DNA-diagnostic assay. Am J Med Genet. 1992:42(3):357-9.

12. Carrwik C, Stenevi U. Lattice corneal dystrophy, gelsolin-type (Meretoja's syndrome). Acta Ophthalmol. 2009;87(8):813-9.

13. Weiss JS, Moller HU, Lisch W, Kinoshita S, Aldave AJ, Belin MW, et al. The IC3D classification of the corneal dystrophies. Cornea. 2008;27 Suppl 2: S1-83. Comment in: Cornea. 2010; 29(12):1469.

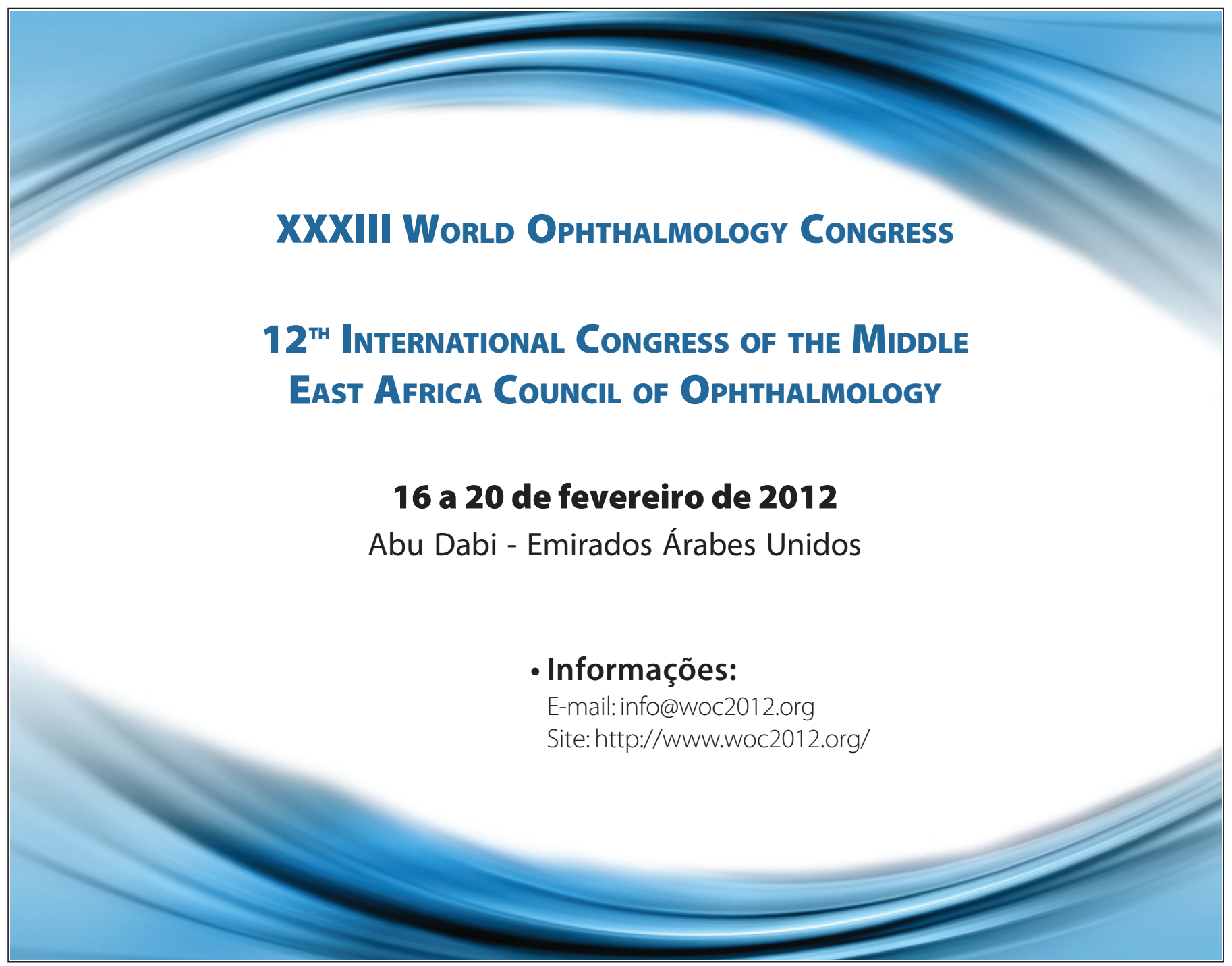

